\title{
LIVING QURAN MEMBANGUN INFRASTRUKTUR \\ IBU KOTA NEGARA BARU REPUBLIK INDONESIA
}

\author{
Syamsuri \\ Institut Agama Islam Negeri Palu \\ Email :syamsuri.akil@gmail.com
}

\begin{abstract}
The Living Quran is a study of the Koran as a holy book that is always "alive" to guide humans, in building and managing the universe. Al-Quran is the most noble reading, guiding the reader (reciter ') when carrying out individual, group, or state activities. AlQuran is a manual book for humans to build infrastructure as the main capital for technological, industrial and economic strength. Building infrastructure in the new capital city of the Republic of Indonesia, begins with zoning in East Kalimantan Province. The launching of the grandbreaking of development, as a prayer asking for grace from Allah SWT, so that work goes according to plan. Munajat is a blessing, in fact it is the living Quran in providing inspiration to project implementers. So that every time you face problems and challenges, there is always a way out (yaj'allahu makhrajan)
\end{abstract}

Key Words: Interpretation, Ideology, and Technology

\section{Abstrak}

Living Quran adalah kajian Al-Quran sebagai kitab suci yang senantiasa "hidup" menuntun manusia, dalam membangun dan mengelola alam semesta raya. Al-Quran adalah bacaan paling mulia, menuntun pembacanya (qari') ketika melaksanakan kegiatan individual, kelompok, atau bernegara. Al-Quran adalah manual book bagi manusia untuk membangun infrastruktur sebagai modal utama kekuatan teknologi, industri, dan ekonomi. Membangun infrastruktur di Ibu Kota Negara baru Republik Indonesia, diawali penetapan wilayah di Provinsi Kalimantan Timur. Launching 
grandbreaking pembangunan, sebagai doa memohon rahmat dari Allah SWT, supaya pekerjaan berjalan sesuai perencanaan. Munajat berkah, sesungguhnya merupakan living Quran dalam memberikan inspirasi bagi pelaksana proyek. Sehingga setiap menghadapi masalah dan tantangan, selalu ada jalan keluarnya (yaj'allahu makhrajan)

Kata kunci : tafsir, ideologi, dan teknologi

\section{Pendahuluan}

Negara Kesatuan Republik Indonesia (NKRI) lahir pada saat Proklamasi Kemerdekaan tanggal 17 Agustus 1945, di Jakarta oleh Ir. Soekarno dan Drs. Muhammad Hatta. Penyebutan "Jakarta" terambil dari deklarasi Fatahillah yang membebaskan Sunda Kelapa dari Portugis pada tanggal. 22 Juni 1527 bertepatan 22 Ramadhan 933 Hijriyah. Keberhasilan Fatahillah merebut Sunda Kelapa kemudian disebut sebagai Fathan Mubina atau kemenangan yang nyata, dalam bahasa Sansekerta disebut jayakarta. Oleh sebab itu, kota Sunda Kelapa diganti oleh Fatahillah menjadi kota Jayakarta atau Jakarta.

Kurang lebih seratus tahun kemudian, 30 Mei 1619 serdadu Belanda berhasil merebut Jakarta dan menggantinya menjadi Batavia, sebagai penghormatan kepada suku bangsa Batavier, leluhur orang-orang Belanda. Batavia kemudian menjadi pusat pemerintahan Hindia Belanda, yang dipimpin oleh Gubernur Jenderal. Ketika Jepang mengalahkan Belanda pada tahun 1942, kebijkan de-Nederlandisasi, kembali menggunakan nama Jakarta, 
hingga Jepang menyerah tanpa syarat kepada sekutu, 15 Agustus 1945.

Sejak 17 Agustus 1945, ibu kota NKRI adalah Jakarta, dengan otoritas pemerintahan Provinsi DKI (Daerah Khusus Ibukota), yang dipimpin seorang gubernur. Sehubungan dengan kondisi DKI Jakarta yang semakin ramai dan menjadi pusat bisnis, maka tercetuslah ide untuk memindahkan ibu kota negara. Presiden Republik Indonesia, Ir. Joko Widodo merespons ide itu, kemudian membentuk tim analisis pemindahan ibu kota negara.

Lokasi Ibu Kota Negara (IKN) baru adalah Kecamatan Sepaku Kabupaten Penajam Paser Utara Provinsi Kalimantan Timur dan Kecamatan Samboja Kabupaten Kutai Kartanegara Provinsi Kalimantan Timur. Kedua wilayah kecamatan tersebut, memiliki jejak warisan sejarah nusantara, yaitu Kerajaan Paser dan Kerajaan Kutai Kartanegara Ing Martadipura. Kerajaan Paser merupakan pengembangan dari Kerajaan Amuntai (kini wilayah Provinsi Kalimantan Selatan), sedangkan Kerajaan Kutai Kartanegara Ing Martadipura memiliki relasi dari Kerajaan Mulawarman.

Ibnu Khaldun menyebutkan pentingnya kedudukan pusat pemerintahan suatu negeri, yaitu :

Syahdan di pusat negara lebih kuat di banding di daerah, dan perbatasan lebih lemah dibanding pusat, sedang di lua perbatasan keadaannya paling lemah. Begitulah bagaikan cahaya bersinar melingkar dari pusat, atau bagaikan lingkaran riak di permukaanm air tempat air itu dipukul. 
Dan apabila usia tua dan kelemahan telah menimpakan suatu negara, maka kemunduran akan bermula di daerahdaerah pinggir. Pusat masih bertahan, hingga Allah memastikan runtuhnya negara itu sama sekali. Dan manakala suatu negara telah dikalahkan di pusatnya, tidak akan berguna kepadanya daerah-daerahnya yang masih tetap berdiri; karena negara yang dalam keadaan demikian itu pasti akan lenyap. Sebab pusat adalah laksana jantung, tempat asal nyawa ditebarkan, dan apabila jantung telah dikuasai, maka anggota badan yang jauh dari jantung akan segera dikuasai pula. ${ }^{1}$

IKN adalah jantung kekuasaan dan kekuatan negara, sehingga jalur-jalur urat nadi mampu mengalirkan kesejahteraan dari Sabang di barat sampai Merauke di timur, serta dari Pulau Miangas di utara hingga Pulau Rote di selatan. Peta geografis Indonesia memiliki 17.504 pulau dengan lima pulau besar; Kalimantan, Sumatera, Jawa, Sulawesi, dan Papua. Luas wilayah laut adalah $3.257 .483 \mathrm{~km}^{2}$ dan luas wilayah darat adalah $1.922 .570 \mathrm{~km}^{2}$. Komposisi luas wilayah kelautan yang sangat besar, perjalanan sejarah nusantara telah melahirkan karakter bahari para pujangga, tokoh, dan perantau.

Ahmad Mansur Suryanegara mengemukakan bahwa mungkinkah ajaran Islam dapat menyebar ke seluruh dunia, jika umat Islamnya tidak memiliki kesadaran kemaritiman. Sangat kontradiktif jika bangsa Arab yang tinggal di Jazirah Arabia, tidak memiliki kesadaran kebaharian. Tidakkah arti jazirah sebagai suatu

${ }^{1}$ Abd al-Rahman bin Muhammad ibn Khaldun, Muqaddimah Ibn Khaldun, Terjemahan Ahmadie Thoha, (Jakarta: Pustaka Firdaus, 1986), h. 198. 
wilayah yang dikelilingi oleh laut dan selat. Nabi Muhammad SAW menyampaikan jawaban pad hal tersebut. Ketandusan Jazirah Arabia dijawab dengan 40 ayat tentang lautan atau maritim. Di dalamnya, bermuatan "wasiat politik kelautan" yang termaktub dalam AlQur'an, yang mengajarkan bahwa Allah SWT telah menyerahkan pengusaan lautan kepada umat Islam. Realitas dunia $71 \%$ terdiri dari lautan dan samudra. Jalan apa yang harus dipilih oleh umat Islam dalam mendakwahkan ajaran Islam ke seluruh dunia. Nusantara Indonesia sebagai negara kepulauan dan produsen rempah-rempah, tersekat jauh antar pulau dan dengan Timur Tengah, India dan Cina oleh lautan dan samudra yang luas. Tidak ada pilihan lain kecuali melalui jalan laut niaga. ${ }^{2}$

Tuhan Sang Pencipta alam semesta, telah menurunkan wahyu sebagai petunjuk mengelola ciptaanNya. Manusia sebagai khalifah (penerima amanah) mengelola potensi insani, flora, dan fauna, sehingga harus menjadikan kitab suci sebagai pedoman pengelolaan. Di antara manusia, ada pilihan Sang Pencipta sebagai pengembang amanah ilahi yaitu Nabi dan Rasul.

Nabi dan Rasul diutus untuk menyempurnakan infrastruktur peradaban dunia. Nabi dan Rasul adalah lambang atau tanda pada akumulasi peradaban manusia. Alam yang dicipta oleh Tuhan lengkap dengan hukum-hukum dan sistem yang teratur, sesuai dengan fungsi-masing-masing. Planet bumi yang dihuni oleh

${ }^{2}$ Ahmad Mansur Suryanegara, Api Sejarah, Jilid 1, (Bandung: Surya Dinasti, 2016), h. 29. 
manusia, terdiri dari mikrokosmos dan makrokosmos. Tuhan mengutus Nabi dan Rasul untuk menyampaikan pesan mikro dan makro yang terdapat di alam raya planet bumi, sehingga manusia mampu mengelola sumber daya alam sesuai dengan sabda Tuhan.

Pranata alam yang dilengkapi dengan elemen-elemen yang melingkupinya, memiliki hubungan yang satu sama lain. Properti alam yang tampak dengan aslinya, ketika diramu antar satu elemen dengan elemen lainnya akan menghasilkan produksi tertentu, sebagai fasilitas yang diberikan oleh Sang Pencipta kepada manusia, supaya dapat bekerja dengan aman dan nyaman. Fasilitas-fasilitas yang tercipta dari macam-macam elemen bumi, disebutlah infrastruktur.

Ibnu Khaldun menyebutkan bahwa daerah yang dimakmurkan (diolah, dibangun, dan didiami manusia) dari bagian bumi yang tidak dilapisi air (kering) terpusat di utara, kerena daerahdaerah utara terlalu dingin dan daerah-daerah selatan terlalu panas untuk didiami oelh manusia. Ujung utara dan ujung selatan merupakan dua puncak yang berlawanan dingin dan panas. Dengan demikian, sudah barang tentu daerah yang terletak di antara dua ujung itu masih kurang dingin atau makin kurang panasnya, sehingga daerah yang ada di tengah antara dua ujung itu sedang hawanya. $^{3}$

\footnotetext{
${ }^{3}$ Khaldun, Muqaddimah Ibn Khaldun, h. 89.
} 
Pada kondisi geospasial, daerah keempat adalah bagian bumi yang sedang hawanya, diikuti oleh daerah ketiga dan kelima; daerah kedua dan keenam makin kurang dari itu, dan selanjutnya tentulah makin kurang lagi daerah pertama dan ketujuh. Penduduk daerahdaerah ini lebih mendekati kesempurnaan karena kesederhanaan mereka. Sederhana dalam tempat kediaman, pakaian, makanan, dan pekerjaan. Rumah mereka dibangun dari batu, dan dihiasi dengan hasil kerajinan. Mereka banyak mempergunakan alat dan perkakas. Memiliki banyak emas, perak, besi, tembaga, timah hitam dan timah putih. Dalam perdagangan, mereka mempergunakan mata uang yang dibikin dari dua macam logam yang berharga, dan mereka menjauhi sifat berlebihan dalam segala hal dan pekerjaan. ${ }^{4}$

Pergerakan dinamika kemajuan tersebut adalah para penduduk Magribi, Suriah, Hejaz, Yaman, dua Irak, India, Shinde, Cina, Spanyol, dan orang-orang Franka (Eropa) yang dekat dengan orang-orang Galisia, Romawi, dan Yunani. Begitu juga pada orangorang yang tinggal di daerah-daerah iklim sedang. Suriah dan Irak adalah daerah yang paling sedang hawanya karena berada dalam kedudukan yang paling tengah dari segala jurusan. ${ }^{5}$

Pada daerah-daerah tersebut, terdapat pengembangan ilmu pengetahuan, pertukangan, bangunan-bangunan, pakaian, makanan, dan buah-buahan. Sebagai pengaruh lingkungan, postur binatangbinatang dan segala apapun yang hidup di daerah tengah itu

\footnotetext{
${ }^{4}$ Khaldun, Muqaddimah Ibn Khaldun, h. 90

${ }^{5}$ Khaldun, Muqaddimah Ibn Khaldun, h, 90
} 
mempunyai ciri-ciri sedang dan sederhana. Umat manusia yang mendiami ketiga daerah tengah tersebut, juga tampak sedang pada tubuhnya, warna kulitnya, sopan santunnya, juga agamanya. Sebagian besar wahyu suci turun di daerah-daerah utara dan selatan. Ini disebabkan, Nabi-nabi dan Rasul-rasul Allah hanya diutus kepada umat yang paling sempurna, baik tubuh maupun pikirannya, yaitu umat yang lebih bisa menerima ajaran yang dibawa oleh Nabinabi dan Rasul-rasul itu. ${ }^{6}$

Firman Allah SWT dalam Al-Quran pada surah Ali Imran ayat 110 :

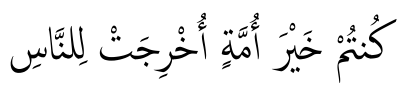

Terjemahnya :

Kamu adalah sebai-baik umat yang telah diciptakan untuk segenap manusia.

Adapun penduduk daerah-daerah yang jauh di ujung seperti penduduk daerah kesatu, kedua, keenam, dan ketujuh, masih berada pada kondisi terkebelakang. Tempat mereka dari tanah liat atau dari sebangsa bamboo. Makanan mereka adalah jewawwut dan buahbuahan liar. Pakaian mereka dari daun-daunan atau kulit. Malah sebagian besar dari mereka pergi ke sana ke mari dengan telanjang bulat. Buah-buahan dan hasil pertanian, belum memadai pengelolaannya. Meereka mempergunakan tembaga, besi, atau

${ }^{6}$ Khaldun, Muqaddimah Ibn Khaldun, h. 91 
kuliat sebagai ganti emas atau perak untuk jual beli. Watak mereka sangat dekat dengan watak binatang buas. Demikian diceritakan bahwa penduduk Negro bertempat tinggal di gua-gua dan pohonpohon besar serta memakan buah-buahan liar. Mereka buas, tak beradab, dan suka makan manusia. Keadaan yang sama juga terdapat pada golongan Slav. ${ }^{7}$

Paradigma pembangunan negeri-negeri yang terdapat dalam kisah dan sejarah, dapat menjadi pedoman dalam perencanaan pembangunan IKN Baru Republik Indonesia. Living Quran akan menyampaikan pedoman Sang Pencipta dalam tata laksana pembangunan infrastruktur berkeadaban, yang memiliki fasilitas yang dibutuhkan oleh penduduk Indonesia.

Al-Quran mengisahkan negeri-negeri yang memiliki taburan fasilitas modern, berkat penerapan ilmu pengetahuan dan teknologi. Para cerdik pandai negeri-negeri itu, mampu memanfaatkan potensi alam menjadi produksi yang bermanfaat bagi penduduknya. Bangunan dengan pahatan dan ukiran pada batu-batu alam, kini menjadi tinggalan arkeologis yang terus menjadi sumber inspirasi pembangunan kluster hunian-hunian modern. Panorama infrastruktur kuno berupa irigasi, sumber daya air, pertanian, peternakan, dan pertambangan, dapat menjadi cakrawala dalam perencanaan pembangunan.

${ }^{7}$ Khaldun, Muqaddimah Ibn Khaldun, h. 90 


\section{B. Metodologi}

Living Quran adalah gabungan dari dua kata, yaitu living, yang berarti 'hidup' dan Quran, yaitu kitab suci umat Islam. Secara sederhana, istilah Living Quran bisa diartikan, "(Teks) al-Quran yang hidup di masyarakat." ${ }^{\text {8 }}$ upaya membumikan al-Quran dengan menikmati kesyahduan alunan irama kitab suci, namun juga memberikan arahan yang riil kepada umat Islam. Etos professional dapat menjadikan al-Quran sebagai sumber inspirasi dan penguat keyakinan untuk berhasil.

Living Quran pada hakekatnya bermula dari fenomena Quran in everyday life, yakni makna dan fungsi al-Quran yang riil dipahami dan dialami masyarakat muslim. Dengan kata lain, memfungsikan al-Quran dalam kehidupan praksis di luar kondisi tekstualnya. Pemfungsian al-Quran seperti ini muncul karena adanya praktek pemaknaan al-Quran yang tidak mengacu pada pemahaman atas pesan tekstualnya, tetapi berlandaskan anggapan adanya "fadhilah" dari unit-unit tertentu teks al-Quran, bagi kepentingan praksis kehidupan keseharian umat. $^{9}$

Heddy Shri Ahimsa-Putra mengklasifikasi pemaknaan terhadap Living Quran menjadi tiga kategori. Pertama, Living

\footnotetext{
${ }^{8}$ Sahiron Syamsuddin, "Ranah-ranah Penelitian dalam Studi al-Qur'an dan Hadis, dalam Sahiron Syamsuddin (ed.), Metode Penelitian Living Qur'an dan Hadis, (Yogyakarta: Teras, 2007), h. xiv.

${ }^{9}$ M. Mansur, "Living Qur'an dalam Lintasan Sejarah Studi Al-Qur'an”, dalam Sahiron Syamsuddin (ed.), Metode Penelitian Living Qur'an dan Hadis, (Yogyakarta: Teras, 2007), h. 5.
} 
Quran adalah sosok Nabi Muhammad SAW. Keterangan Aisyah binti Abu Bakar Ash-Shiddiq ketika ditanya tentang akhlak Nabi Muhammad SAW, beliau menjawab bahwa akhlaq Nabi SAW adalah al-Quran. ${ }^{10}$ Dengan demikian Nabi Muhammad SAW adalah “al-Quran yang hidup," atau Living Quran. Kedua, ungkapan Living Quran juga bisa mengacu kepada suatu masyarakat yang kehidupan sehari-harinya menggunakan al-Quran sebagai kitab acuannya. Mereka hidup dengan mengikuti apa-apa yang diperintahkan alQuran dan menjauhi hal-hal yang dilarang di dalamnya, sehingga masyarakat tersebut seperti "al-Quran yang hidup", al-Quran yang mewujud dalam kehidupan sehari-hari. Ketiga, ungkapan tersebut juga dapat berarti bahwa al-Quran bukanlah hanya sebuah kitab, tetapi sebuah "kitab yang hidup", yaitu yang perwujudannya dalam kehidupan sehari-hari begitu terasa dan nyata, serta beraneka ragam, tergantung pada bidang kehidupannya. ${ }^{11}$

M. Quraish Shihab, dalam karyanya Membumikan Al-Quran Fungsi dan Peran Wahyu Dalam Kehidupan Masyarakat, lebih lanjut mengemukakan sebagai berikut :

Bangsa Indonesia, di bawah pimpinan pemerintahnya, sejak 1945 berusaha untuk mengisi kemerdekaan yang telah kita

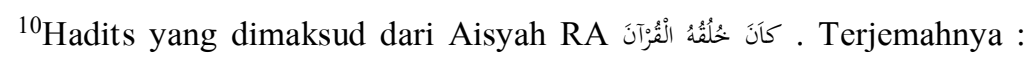
Akhlak Rasulullah adalah al-Qur'an. Ahmad bin Muhammad bin Hanbal Abu Abd Allah al-Shaybani, Musnad Ahmad bin Hanbal, (Kairo : Dar al-Hadis, 2013), h. $41 / 149$

${ }^{11}$ Heddy Shri Ahimsa-Putra, "The Living Al-Qur'an: Beberapa Perspektif Antropologi", dalam Jurnal Walisongo 20, 1 (Semarang : UIN Walisongo, 2012), h. 236-237. 
proklamirkan dengan melaksanakan "pembangunan", walaupun istilah ini belum dikenal waktu itu. Pembangunan yang dilaksanakan tersebut, pada dasarnya, adalah upaya dan ikhtiar segenap bangsa Indonesia untuk mengadakan perubahan, peningkatan mutu dan kualitas bangsa, secara sadar, berencana, terarah dan menyeluruh. Setiap bangsa yang melaksanakan pembangunan harus bertolak dari kenyataan, nilai, norma, dan pandangan hidup bangsa itu. Dalam hal ini, untuk bangsa Indonesia adalah Pancasila dan Undang-Undang Dasar 1945.

Apa yang dikemukakan ini telah merupakan kesepakatan nasional yang disadari kepentingan dan urgensinya oleh semua pihak, termasuk pemerintah dan ulama. Ulama, yang menyadari kedudukan mereka sebagai pewaris para nabi, merasa berkewajiban untuk terlibat secara langsung dalam pembangunan, bukan hanya terbatas dalam memberikan nasihat dan fatwa, tetapi juga keterlibatan dalam bidang-bidang perencanaan, pelaksanaan dan pengawasan pembangunan, serta menilai baik-buruknya dampak yang diberikannya berdasarkan nilai-nilai yang diamanatkan Tuhan melalui Kitab Suci-Nya. ${ }^{12}$

Kaitannya dengan tulisan ini, Living Qur'an adalah kajian tentang pembangunan infrastruktur IKN baru Republik Indonesia. Landasan pembangunan yang disinari oleh cahaya Al-Qur'an, akan menghasilkan fasilitas umum yang bermanfaat untuk manusia dan kemanusiaan. Nusantara adalah bumi Allah, tentunya petunjuk pengelolaannya, pasti sudah diterangkan dalam wahyu yang diturunkan kepada para utusanNya.

${ }^{12}$ M. Quraish Shihab, Membumikan Al-Quran Fungsi dan Peran Wahyu Dalam Kehidupan Masyarakat (Bandung: Mizan, 1996), h. 379-380. 


\section{Pembangunan Infrastruktur di IKN}

Setelah Presiden Republik Indonesia menetapkan lokasi IKN, maka beberapa pekerjaan pembangunan infrastruktur yang dilakukan, antara lain :

1. Sayembara desain IKN

Pemenang sayembara desain IKN Baru Republik Indonesia, adalah Tim Urban+ dengan tema "Nagara Rimba Nusa". Desain IKN yang mewujudkan keseimbangan pembangunan manusia dengan alam, tidak menghalangi aliran angin, tidak mengambil air terlalu banyak dari alam, tapi dari lahan yang memang sudah ditangkap secara natural. Pusat pemerintahan negara yang mampu memanfaatkan sumber daya manusia dalam menata kekuatan dan panorama alam.

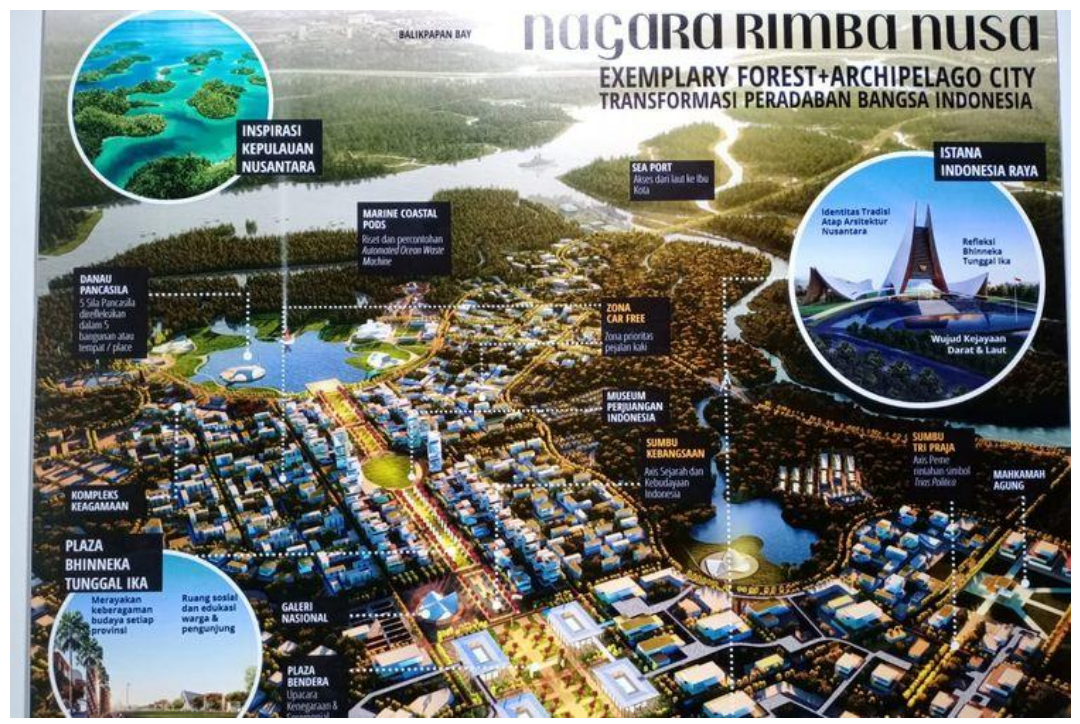

Gambar 1 
"Nagara Rimba Nusa"

Juara Pertama Sayembara Gagasan Desain IKN

(Kompas.com)

Menurut Menteri Pekerjaan Umum dan Perumahan Rakyat Republik Indonesia, Basuki Hadimuljono, pemenang desain IKN memenuhi tiga kriteria. Pertama, IKN sebagai identitas bangsa untuk kemajuan peradaban negara Indonesia. Kedua, keberlanjutan kota yang ramah lingkungan (environmental friendly), baik dari sosial ekonomi, dan kebencanaan. Ketiga, kota bukan untuk generasi saat ini, tetapi untuk generasi yang akan datang. Karena itu, kota harus dirancang dengan desain yang menekankan pada kecerdasan, modern, dan memenuhi standar internasional. ${ }^{13}$

Rimba nusa yang berwujud dalam bentuk zamrut khatulistiwa, adalah anugerah kekayaan alam, yang harus dikuasai oleh negara dan dimanfaatkan sebesar-besarnya untuk kemakmuran rakyat Indonesia. Kekayaan laut dengan potensi protein ikan, rumput laut, sumber daya mineral, hingga laut menjadi jalan raya lalu lintas antar pulau. Kekayaan wilayah darat, meliputi pertanian, peternakan, perkebunan, perikanan, kehutanan, pertambangan, hingga pemandangan laut, lembah, dan gunung.

Perangkat pembangunan infrastruktur yang tampaknya fisik, namun terdapat pula unsur-unsur ideologi, teologis, dan ekologis. Ketua Tim Urban+ yang memenangkan sayembara desain IKN, Sibarani, mengemukakan bahwa ide dasar desain ini, adalah

\footnotetext{
${ }^{13}$ Hilda B. Alexander, "Nagara Rimba Nusa", Juara Pertama Sayembara Gagasan Desain IKN, (Jakarta : Kompas.com, 2019), 1. 
menghubungkan antara masyarakat dengan alam dan lingkungan. Kawasan Sepaku sebagai IKN baru tak lepas dari kehidupan air (bahari). Oleh karena itu, konsep desain diupayakan mendekati tepi air. Ini adalah sebuah upaya bagaimana kami mewujudkan keseimbangan antara pembangunan fisik, pembangunan manusia, sifat manusia, dan proses adaptasinya dengan alam. Tidak boleh, salah satu di antaranya mengorbankan yang lainnya. Karena itu, ruh dari konsep desain ini sejatinya adalah keseimbangan yang direpresentasikan dalam sistem perkotaan atau biasa disebut biomimicri. Bio-mimicri adalah sebuah pendekatan untuk menciptakan inovasi atau solusi guna menjawab tantangan yang dihadapi manusia dengan cara meniru pola yang sudah ada dan teruji alam. Tujuan dari bio-mimicri adalah untuk mencapai sebuah produk, proses dan caracara yang baru untuk kita hidup dan beradaptasi di bumi dalam jangka waktu yang panjang. ${ }^{14}$

Allah SWT menjelaskan dalam Al-Quran, tentang manfaat keseimbangan pembangunan sebuah negeri. Pada surah al-A'raf ayat 96, yaitu:

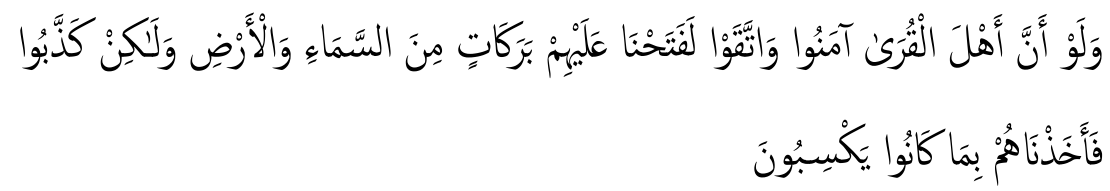

Terjemahnya :

14 Alexander, "Nagara Rimba Nusa", Juara Pertama Sayembara Gagasan Desain IKN, h. 1. 
Jikalau sekiranya penduduk negeri-negeri beriman dan bertakwa, pastilah Kami akan melimpahkan kepada mereka berkah dari langit dan bumi, tetapi mereka mendustakan (ayat-ayat Kami) itu, maka Kami siksa mereka disebabkan perbuatannya.

Pemenuhan kemuliaan dalam sistem pengelolaan negara, yang ditandai dengan pembangunan pusat pemerintahan berlandaskan anjuran dari Sang Pencipta melalui kitab suci-Nya, maka potensi pengembangan kesejahteraan sosial akan tercapai. Inilah yang selalu disebut dalam bahasa Al-Quran, yaitu berkah.

Limpahan berkah dari langit dan bumi, menunjukkan adanya kemampuan profesional dalam penguasaan ilmu pengetahuan yang menghasilkan teknologi. Pengelolaan teknologi menghasilkan industri. Industri meghasilkan produksi berupa alat dan barang. Pemasaran alat dan barang memunculkan pekerjaan jasa. Pada tataran ini lahirlah istilah produsen dan konsumen. Sirkulasi alat dan barang dari produsen ke konsumen, yang menghadirkan peristiwa ekonomi. Sejarah pertukaran barang dengan barang dikenal dengan nama barter. Pada zaman modern, alat tukar itu disebut mata uang. Sejarah Islam, telah mempersembahkan alat tukar dalam bentuk emas yang disebut dinar dan alat tukar dalam bentuk perak disebut dirham.

2. Pembangunan Jembatan di Teluk Balikpapan

Pembangunan jembatan di Teluk Balikpapan, tepatnya di Pulau Balang, untuk memudahkan akses dari dan ke IKN baru Republik Indonesia. Jembatan sepanjang 804 meter dengan lebar 24 
meter menghubungkan Kota Balikpapan dengan Kabupaten Penajam Paser Utara. Selama ini, andalan transportasi adalah kapal ferry, yang melintasi kedua daerah, yang kemudian terkoneksi dengan daerah-daerah lainnya.

Moda transportasi laut dan darat di IKN, akan menambah variasi akses masyarakat, untuk mewujudkan lalu lintas antar industri dengan pertanian, perkebunan, peternakan, perikanan, dan kehutanan. Penerapan alat-alat industri dalam kehidupan manusia, semakin meningkat seiring dengan globalisasi kehidupan sosial. Percepatan akses kebutuhan primer, akan mendorong tercapainya kesejahteraan sosial dan kemakmuran universal.

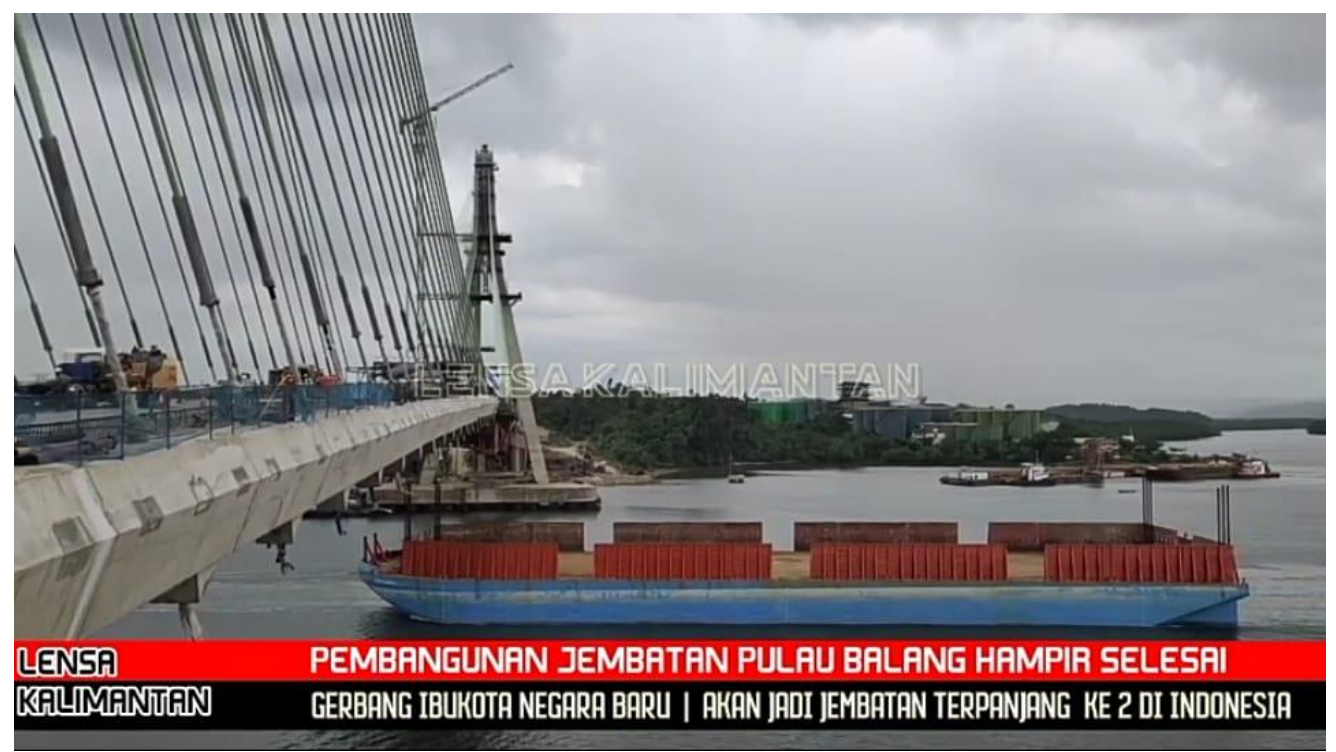

Gambar 2

Pembangunan Jembatan di Teluk Balikpapan

(Youtube.com) 
Sehubungan dengan prakarsa pembangunan transportasi laut dan darat, sesuai dengan firman Allah SWT dalam al-Qur'an pada surah al-Baqarah ayat 164 :

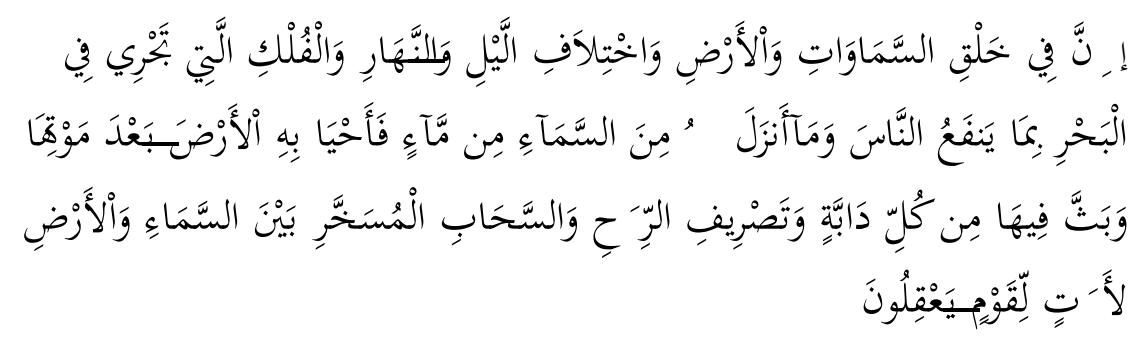

Terjemahnya :

Sesungguhnya dalam penciptaan langit dan bumi, silih bergantinya malam dan siang, bahtera yang berlayar di laut membawa apa yang berguna bagi manusia, dan apa yang Allah turunkan dari langit berupa air, lalu dengan air itu Dia hidupkan bumi sesudah mati (kering)-nya dan Dia sebarkan di bumi itu segala jenis hewan, dan pengisaran angin dan awan yang dikendalikan antara langit dan bumi; sungguh (terdapat) tanda-tanda (keesaan dan kebesaran Allah) bagi kaum yang memikirkan.

Penerapan ayat tersebut jelas terlihat pada wilayah IKN. Posisi Kota Balikpapan sebagai pintu gerbang IKN, sudah terjalin hubungan pemasaran sayur, buah, kambing, sapi, ayam dan komoditi pangan lainnya dari pulau Jawa, Sulawesi, Sumatera, dan pulaupulau lainnya. Pelabuhan Laut Semayang Balikpapan, setiap hari menerima kapal-kapal berlabuh mengangkut komoditi pertanian, peternakan, perkebunan, perikanan, dan kehutanan. Demikian pula 
Bandar Udara Sultan Aji Muhammad Sulaiman Balikpapan, setiap hari menjadi lalu lintas penduduk dalam melintasi udara Republik Indonesia.

Pada pelaksanaan Pekan Olahraga Nasional (PON) XVII tanggal 27 Juni hingga 5 Juli 2008, lokasi pertandingan paralayang diadakan di Matantimali Kabupaten Sigi Provinsi Sulawesi Tengah. Penetapan lokasi ini sebagai ajang olahraga perasut terbang, karena kondisi angin yang berhembus selalu stabil sepanjang tahun. Para atlet paralayang dilengkapi dengan deteksi kekuatan angin, sehingga mampu membuat perencanaan kapasitas waktu dan ketinggian jelajah udara, sebelum mendarat di garis finis.

Asas utama pembangunan infrastruktur adalah untuk memudahkan aktifitas hidup manusia. Fungsionalisasi bangunan infstruktur merupakan pengejawantahan ajaran agama, yang mendorong umat manusia untuk belajar, bekerja, saling menyayangi, dan saling mengasihi. Bangunan rumah ibadah, rumah tempat tinggal, rumah makan, toko, kampus, kantor, pabrik, jalan raya, irigasi, dan lain-lain, merupakan fungsional pendukung pekerjaan warga negara.

Jadi, pembangunan infstruktur adalah fasilitas yang merelasikan antara sumber daya alam dengan sumber daya manusia. Pelestarian lingkungan hidup berbanding lurus dengan fungsionalisme infrastruktur. Sebuah bangunan yang tidak lagi memiliki daya dukung lingkungan, maka bangunan itu pasti 
ditinggalkan oleh pemakainya, dan bahkan ambruk karena abrasi dan erosi.

Indeks keseimbangan pembangunan infrastruktur, terdapat dalam al-Qur'an, yaitu :

1. Al-hayah (hidup) dan al-maut (mati), masing-masing sebanyak 145 kali.

2. Al-naf' (manfaat) dan al-madarrah (mudarat), maisng-masing sebanyak 50 kali.

3. Al-har (panas) dan al-bard (dingin), masing-masing 4 kali.

4. Al-thuma'ninah (kelapangan / ketenangan) dan al-dhiq (kesempitan / kekesalan), masing masing 13 kali.

5. Al-rahbah (cemas/takut) dan al-raghbah (harap/ingin), masingmasing 8 kali.

6. Al-kufr (kekufuran) dan iman (iman) dalam bentuk indifinite, masing-masing 8 kali.

7. Al-shayf (musim panas) dan al-syita' (musim dingin), masingmasing 1 kali.

8. Al-harts dan al-zira'ah (membajak / bertani), masing-masing 14 kali.

9. Al- 'ushb dan al-dhurur (membanggakan diri / angkuh), masingmasing 27 kali.

10. Al-dhallun dan al-mawata (orang sesat / mati [jiwanya]), masing-masing 17 kali.

11. Al-Qur'an, al-wahyu, dan al-Islam (Al-Qur'an, wahyu dan Islam), masing-masing 70 kali. 
12. Al- 'aql dan al-nur (akal dan cahaya), maisng-masing 49 kali.

13. Al-jahr dan al-'alaniyah (nyata), masing-masing 16 kali.

14. Al-infaq (infak) dengan al-ridha (kerelaan), masing-masing 73 kali

15. Al-bukhl (kekikiran) dengan al-hasarah (penyesalan), masingmasing 12 kali.

16. Al-kafirun (orang-orang kafir) dengan al-nar/al-ahraq (neraka/pembakaran), masing-masing 154 kali.

17. Al-zakah (zakat/penyucian) dengan al-barakat (kebajikan yang banyak), masing-masing 32 kali.

18. Al-fahisyah (kekejian) dengan al-ghadhb (murka), masingmasing 26 kali.

19. Al-israf (pemborosan) dengan al-sur'ah (ketergesa-gesaan), masing-masing 23 kali.

20. Al-maw'izah (nasihat/petuah) dengan al-lisan (lidah), maisngmasing 25 kali.

21. Al-asra (tawanan) dengan al-harb (perang), masing-masing 6 kali.

22. Al-salam (kedamaian) dengan al-thayyibat (kebajikan), masingmasing 60 kali.

23. Kata yawm (hari) dalam bentuk tunggal sejumlah 365 kali, sebanyak hari-hari dalam setahun. Sedangkan kata hari yang menunjuk kepada bentuk plural (ayyam) atau dua (yawmayni), jumlah keseluruhannya hanya 30, sama dengan jumlah hari dalam sebulan. Di sisi lain, kata yang berarti "bulan” (syahr) 
hanya terdapat 12 kali, sama dengan jumlah bulan dalam setahun.

24. Al-Qur'an menjelaskan bahwa langit ada "tujuh". Penjelasan ini diulanginya sebanyak tujuh kali pula, yakni dalam alBaqarah ayat 29, al-Isra' ayat 44, al-Mu'minun ayat 86 , Fushshilat ayat 12, al-Thalaq ayat 12, al-Mulk ayat 3, dan Nuh ayat 15 . Selain itu, penjelasannya tentang terciptanya langit dan bumi dalam enam hari dinyatakan pula dalam tujuh ayat.

25. Kata-kata yang menunjuk kepada utusan Tuhan, baik rasul (rasul), atau nabiyy (nabi), atau basyir (pembawa berita gembira), atau nadzir (pemberi peringatan), keseluruhannya berjumlah, 518 kali. Jumlah ini seimbang dengan jumlah penyebutan nama-nama nabi, rasul dan pembawa tersebut, yakni 518 kali. $^{15}$

Rencana pembangunan secara fisik di IKN adalah istana presiden, gedung-gedung lembaga eksekutif, lembaga legislatif, dan lembaga yudikatif. Ketiga unsur lembaga pemerintahan, yang disebut trias politica dibangun di titik nol IKN Sepaku, pada sebuah bukit yang cukup tinggi yang kemudian dilengkapi dengan tatanan keseimbangan ekologis. ${ }^{16}$

\section{Kesimpulan}

${ }^{15}$ Shihab, Membumikan Al-Quran Fungsi dan Peran Wahyu Dalam Kehidupan Masyarakat, h. 29-31.

${ }^{16}$ Hilda B. Alexander, "Nagara Rimba Nusa", h. 1. 
Berdasarkan hasil kajian Living Quran membangun infrastruktur IKN baru Republik Indonesia di Provinsi Kalimantan Timur, dapat dikemukakan beberapa kesimpulan, sebagai berikut:

1. Firman Allah SWT dalam Al-Quran menerangkan tentang pembangunan infrastruktur sebuah negeri, harus berdasarkan tingkat kegunaan penduduknya, sehingga orientasi pemeliharaannya berlangsung secara partisipatif.

2. Pembangunan infrstruktur di IKN berlangsung sesuai dengan perencanaan, sehingga terintegrasi dengan sistem pembangunan nasional. Keseimbangan ekonomi dan ekologi dapat meningkatkan kualitas kehidupan berbangsa dan bernegara.

3. Semangat keagamaan bangsa Indonesia di saat pelaksanaan pembangunan di IKN akan menambah berkah spiritual dan material, yang memang menjadi hakikat pembangunan semesta nasional

\section{DAFTAR PUSTAKA}

Khaldun, Abd al-Rahman bin Muhammad ibn. Muqaddimah Ibn Khaldun, Terjemahan Ahmadie Thoha. Jakarta : Pustaka Firdaus, 1986.

Al-Shaybani, Ahmad bin Muhammad bin Hanbal Abu Abd Allah. Musnad Ahmad bin Hanbal. Kairo: Dar al-Hadis, 2013.

Suryanegara, Ahmad Mansur. Api Sejarah, Jilid 1. Bandung: Surya Dinasti, 2016. 
Heddy Shri Ahimsa-Putra, "The Living Al-Qur'an: Beberapa Perspektif Antropologi", dalam Jurnal Walisongo 20, 1 Semarang : UIN Walisongo, 2012.

Alexander, Hilda B. Alexande. "Nagara Rimba Nusa", Juara Pertama Sayembara Gagasan Desain IKN, (Jakarta : Kompas.com, 2019.

M. Mansur, "Living Qur'an dalam Lintasan Sejarah Studi AlQur'an", dalam Sahiron Syamsuddin (ed.), Metode Penelitian Living Qur'an dan Hadis. Yogyakarta: Teras, 2007.

Shihab, M. Quraish. Membumikan Al-Quran Fungsi dan Peran Wahyu Dalam Kehidupan Masyarakat. Bandung: Mizan, 1996.

Syamsuddin, Sahiro. "Ranah-ranah Penelitian dalam Studi alQur'an dan Hadis, dalam Sahiron Syamsuddin (ed.), Metode Penelitian Living Qur'an dan Hadis. Yogyakarta: Teras, 2007. 